was negative, and the reaction with tetranitromethane was weakly positive. In the slide germination test, the substance completely inhibited the spore germination of Penicillium italicum at a concentration of 45 p.p.m.

The available data indicate that the compound is not entirely pure and apparently contains an unsaturated hydrocarbon, probably of olefinic character, with thirty to thirty-five carbon atoms. The oxygen content of 1.42 per cent indicated by the microanalysis is most probably due to partial oxidation. A hydrocarbon isolated by Naudin ${ }^{4}$ from Matricaria chamomilla was also found to contain $1 \cdot 5-1 \cdot 8$ per cent of oxygen, whereas Francis, Watkins and Wallington ${ }^{5}$ showed that paraffin wax fractions are partially oxidized when air is introduced at $100^{\circ} \mathrm{C}$. The substance appeared to be rather unstable. Fungistatically active fractions containing the substance decrease in activity on standing, notably when dissolved in benzene, and resinify at temperatures higher than $100^{\circ} \mathrm{C}$. with complete loss of activity.

For purposes of comparison, the cis-olefine with thirty-five carbon atoms, pentatriacontene-17, was synthesized from stearic acid by the method of Grün et al. ${ }^{6}$. This compound consists of transparent silverwhite plates and possesses physical properties very similar to those of the isolated product ; it is, however, fungistatically inactive.

These investigations are being continued. H. L. KIÖPPING

G. J. M. VAN DER KERK

Institute for Organic Chemistry T.N.O.,

Utrecht. Feb. 3.

${ }^{2}$ Grosjean, J., Nature, 165, 853 (1950).

Manten, A., Klöpping, H. L., and van der Kerk, G. J. M. “'Ant. van Leeuwenhoek", 16, 282 (1950).

${ }^{3}$ Gomberg, M., and Buchler, C. C., J. Amer. Chem. Soc., 42, 2663 (1920)

4 Naudin, E., Bull. Soc. Chim. France, 485 (1884)

${ }^{5}$ Francis, F., Watkins, C. M., and Wallington, R. W., J. Chem. Soe., 121, $2804(1922)$.

6 Grün, A., Ulbrich, E., and Krezil, F., Z. angew. Chem., 39. 424 (1926).

\section{Calculation of the Digestibility of the Protein in Silage}

IT has been shown by Barnett and Miller ${ }^{1}$ that the relationship between the soluble nitrogen content $\left(N_{s}\right)$ and the total nitrogen content $\left(N_{d}\right)$ of dried samples of grass silage can be represented by the formula : $N_{s} / N_{d}=0.854-0.100 p \mathrm{H} \pm 0.012$. As the quality of silage is related to its $p \mathrm{H}$, it seomed desirable to estimate the digestibility of the protein in dried silage by the pepsin method of Wedemeyer'. This method has fallen into disuse as it is stated to give results which are too high, but, so far as we are aware, no critical study of the method in connexion with silage exists. A study of the protein digestibility of the samples previously examined (about seventy in number) for their soluble nitrogen content revealed that a direct relationship existed between the soluble nitrogen content and the digestible protein content $\left(N_{p}\right) /\left(N_{d}\right)$. This relationship is given by the formula $N_{p} / N_{d}=33.4+0.78 \quad N_{s} / N_{d} \pm 0.07$. It is possible then, with regard to dried grass silage, to portray the nitrogen state, so to speak, as in Fig. 1, the results there being shown on a percentage basis. As the direct determination of $N_{p} / N_{d}$ involves a pepsin digestion which lasts forty-eight hours, whereas the corresponding operation of washing the dried silage to determine $\Lambda_{s} / \Lambda_{d}$ takes only forty minutes, the time saved by this method of approach is obvious.

Watson ${ }^{3}$ has shown that the arnount of digestible crude protein in silage can be calculated from the

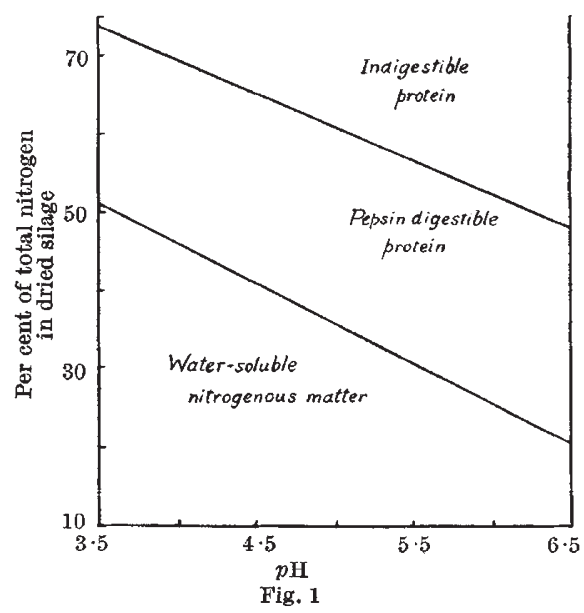

formula, Dig.C.P. $=0.8179 \mathrm{CP}-2.415$; but he stresses that this formula applies only to well-made silage. Dijkstra ${ }^{4}$ has evolved three formulæ for the calculation of the digestible crude protein content of silage applicable to silage of three main quality groups. In Fig. 2 are shown the results obtained by calculating the digestible crude protein contents according to the methods of Watson, Dijkstra and

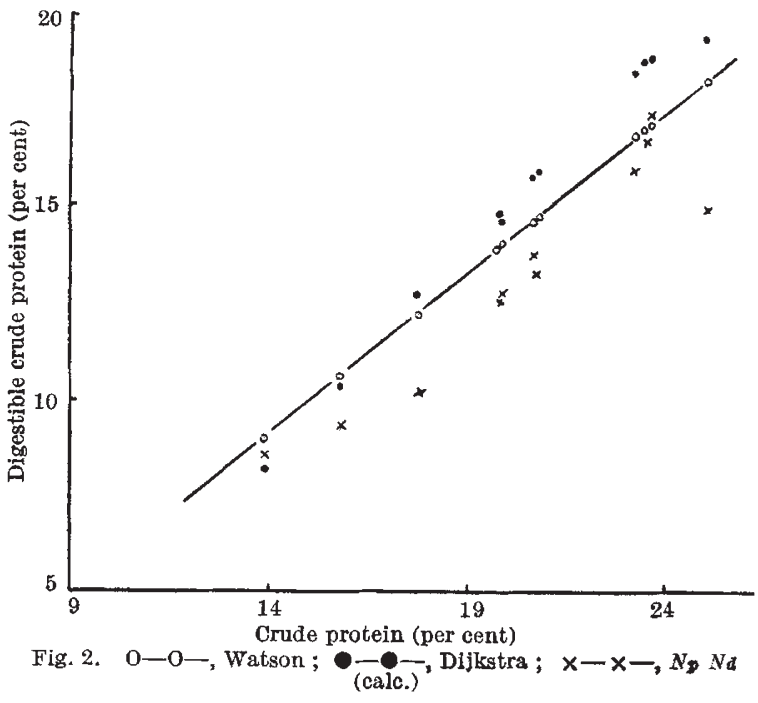

our formula for $N_{p} / N_{d}$. Each point in this graph represents the average result obtained by the examination of twelve or more samples from a given tower or pit. Among other things it will be noted that, in general, the results obtained by the third method are lower than those obtained by either Watson's or Dijkstra's method.

Preliminary studies indicate that the results obtain. able in the laboratory are reproducible in feeding trials, and a fuller account of this work will appear elsewhere at a later date.

A. John G. BARneTt

T. B. MILLER

Division of Agricultural Biochemistry, Department of Biological Chemistry, University of Aberdeen.

1 Barnett, A. J. G., and Miller, T. B., J. Agric. Sci., 40, 50 (1950). ${ }^{2}$ Wedemeyer, K., Landw. VersSta., 51, 375 (1899).

"Watson, S. J., "Science and Practice of Conservation : Grass and Forage Crops", 508 (Pub by Fertil, and Feed.-St. J., 1939). " Dijkstra, N. D., Versl. Landbouwk. Onderzoek., No. 55, 10 (1949). 